\title{
The Political Participation of People with Disabilities (Feebleminded) in 2019 Election in Riau Province
}

\author{
Alexsander Yandra ${ }^{1}$, Andrizal $^{1}$, Yulianti Asyar ${ }^{1}$ \\ \{alexsy@unilak.ac.id\} \\ Lancang Kuning University, Indonesia ${ }^{1}$
}

\begin{abstract}
This study examined the problem of democracy as governmental system which placed the people as the sole vote holder through the Election process. Election defined as an activity which is considered as a form or parameter of a democratic country. However, the implementation of election is full of problems, namely the lack of participation of people with disabilities and even it tends to be mobilized in the 2019 election in Riau Province. This study used the approach of democratic theory and political participation as well as qualitative methodology through analysis of ethical and emic interpretation data so that this study explained the political participation of people with disability (feebleminded) was still below the political percentage of Riau community which was $45 \%$ and was merely procedural and even not independent. This was because there was no special mechanism for them to participate in the election which then had implication on the neglected voting right.
\end{abstract}

Keywords: Participation, Disabilities, Democracy, Election.

\section{Introduction}

Democracy is also understood as a governmental system which places the people as the sole vote holder through the election process [1]. Talking about democracy certainly cannot be separated from politics, because to realize a democratic country requires active political participation from its citizens. Essentially, participation is the involvement of a person or a group of people in a larger activity. Participation only has meaning if it is accompanied by a sense of responsibility by those who take part in the activity. The term of political participation is applied to the activities of people at all levels of the political system like a voter who participates in giving his/her vote [2]. According to Budiardjo [3] states "Political participation is the activity of a person to actively participate in political life by choosing the leader of the country which directly or indirectly influences the policy of government. Election as a means of democratization has been used in some countries including Indonesia, which has a heterogeneous society. Indonesia helds a democratic party with the aim of electing the members of Legislative and Executive President/Regional Head [4]. The principle of democracy is a set of values which becomes the basis of the realization democratic political system, the principles of democracy play an important role as a guide and benchmark for the success of a country or a government in realizing a democratic political system. Without the principle of democracy, not only political orientation will become vague but also the meaning of holding the government itself will also be more absurd. The issue which is no less important for upholding the principle of democracy is the direct involvement of the people or or the people with disabilities [5]. 
The implementation of 2019 election in Indonesia was still full of problems, one of them was in Riau Province related to the political participation of people with disabilities. The involvement of people with disabilities became problematic in general when there were no difference in the voting right during the voting process. Generally, people with disabilities are divided into four groups, namely physical disability, intellectual disability, mental disability, and sensory disability. In fact, the issues spread in the media, crazy people are chosen to become a serious concern related to the categorization of intellectual disability group. This study focuses on intellectual disability which is caused by the disruption of thought function because the intelligence is below the average. For example, slow learning, feebleminded and down syndrome. Feebleminded is someone who has low intellectual capacity (IQ) accompanied by an inability to adapt to his environment so that he has various social problems.

To describe it, it is necessary to have information and data on Permanent Voters with Disabilities by type in Riau Province, as follows:

\begin{tabular}{|c|l|c|}
\hline No & \multicolumn{1}{|c|}{ Type of Disability } & Total \\
\hline 1. & Physical disability & 1.292 \\
\hline 2. & Blind & 832 \\
\hline 3. & Deaf & 1.146 \\
\hline 4. & Feebleminded & 911 \\
\hline 5. & Other disabilities & 837 \\
\hline & Total & 4.995 \\
\hline
\end{tabular}

Source: Regional General Election Commission of Riau Province Riau Province.

From the table above, it can be seen that the data of permanent voters with disabilities has four types, namely physical disability, blind, deaf and feebleminded. However, from the four types of disabilities mentioned from the time span of the implementation of general election of the governor of Riau and 2019 election, people with disabilities who are feebleminded is increase every year. The following is the data on the level of permanent voters with disabilities who are feebleminded in Riau governor election in 2018 with 2019 election in Riau Province as follows:

\begin{tabular}{|c|l|c|}
\hline No & \multicolumn{1}{|c|}{ Year } & $\begin{array}{c}\text { Total of People with Disability } \\
\text { (Feebleminded) }\end{array}$ \\
\hline 1. & 2018 Riau Governor Election & 660 voters \\
\hline 2. & 2019 Election & 911 voters \\
\hline & Difference & 251 voters \\
\hline
\end{tabular}

Source: Regional General Election Commission of Riau Province.

Based on the above table, it can also be seen that the data for the voters with disabilities who are feebleminded in Riau Province have increased for 2018-2019, namely in the implementation of Riau Governor Election and 2019 Election. This reality is an interesting issue in this study where the voters with disabilities (feebleminded) have increased, but whether it is linear with their participation in voting rights. According to Dewi [6] the reduction of participation rate is counterproductive to the guarantee of the implementation of political rights without discrimination, especially among people with disabilities. The political participation of 
people with disabilities has a very important role in preparing a reference basis for empowering and strengthening the capacity of marginalized disabled groups. It is important that the strengthening in political participation is no longer trapped in the hustle and the bustle of voting, but also substantially encourages this community to make a change movement [7].

The political participation of people with disabilities is a deepening study of political science, especially in democracy and election, where the involvement is still dependent on the companion when voting. There is no specific model for them to be able to participate in the election so that it makes them vote not based on their own awareness.

\section{Method}

This study used qualitative method with drawing informant technique which prioritizes on the quality of data obtained through the delivery of informant related to the research problem. To get the right data, the researcher used several data collection techniques, namely in-depth interview, documentation, collecting data and making conclusion so that it is easily understood by the researcher itself and others people [8]. All data obtained was analyzed using qualitative method through interpretation. This process classified data into two parts, namely ethical data (from theory) and emic data (from field findings). Furthermore, the process of reducing the results of data analysis can be measured and able scientifically justified even become new finding in developing political participation theory.

\section{Results and Discussion}

\subsection{Political Participation of People with Disabilities}

People with disabilities are community groups who have limitations which hinder their participation in the community life. A person with disability is not merely disability but he is also the result of interaction from the limitations experienced by a person with his environment. Not only physical or mental, but it is a phenomenon which consists of bodily function, limited activities, barriers on participation and environmental factors.

In this context to increase political participation of voters with disabilities there needs to be special attention from the election organizer which is Regional General Election Commission. As the organizer, Regional Election Commission must be able to provide a means for the people especially for the people with disabilities to participate in political activities. Therefore, this political participation is carried out through participation in voting during the election.

One of the indicators of political participation in the election is voting. The Regional General Election Commission as the organizer of election whose duty is to carry out the election, has an obligation to meet all the needs of the citizens in order to be able to do his own right to vote independently and easily, and to be able to uphold the principles of election. Voting is an activity carried out by a group of people or many people as well as people with disabilities to elect the leader or representative. In this case, to find out the participation of voters with disabilities in Riau Province in voting in 2019 election can be seen from the following table: 


\begin{tabular}{|c|l|c|c|c|c|c|c|c|c|}
\hline No & $\begin{array}{l}\text { Regency/ } \\
\text { City }\end{array}$ & $\begin{array}{c}\text { The } \\
\text { Number of } \\
\text { Village/ } \\
\text { groups }\end{array}$ & $\begin{array}{c}\text { Number of } \\
\text { Polling } \\
\text { Station }\end{array}$ & $\begin{array}{c}\text { Physical } \\
\text { Disability }\end{array}$ & Blind & Deaf & $\begin{array}{c}\text { Feeblem- } \\
\text { inded }\end{array}$ & $\begin{array}{c}\text { Other } \\
\text { Disabilities }\end{array}$ & $\begin{array}{c}\text { Total of } \\
\text { people with } \\
\text { disabilities }\end{array}$ \\
\hline 1 & Kampar & 21 & 2.229 & 181 & 86 & 170 & 119 & 118 & 674 \\
\hline 2 & $\begin{array}{l}\text { Indragiri } \\
\text { Hulu }\end{array}$ & 14 & 1.204 & 127 & 98 & 164 & 97 & 106 & 592 \\
\hline 3 & Bengkalis & 11 & 1.800 & 49 & 32 & 52 & 54 & 24 & 211 \\
\hline 4 & $\begin{array}{l}\text { Indragiri } \\
\text { hilir }\end{array}$ & 20 & 1.994 & 177 & 191 & 163 & 72 & 62 & 665 \\
\hline 5 & Siak & 14 & 1.244 & 122 & 41 & 97 & 118 & 95 & 473 \\
\hline 6 & Pelalawan & 12 & 941 & 40 & 85 & 62 & 32 & 63 & 282 \\
\hline 7 & $\begin{array}{l}\text { Kepulauan } \\
\text { Meranti }\end{array}$ & 9 & 655 & 36 & 39 & 44 & 32 & 58 & 209 \\
\hline 8 & $\begin{array}{l}\text { Kuantan } \\
\text { Singingi }\end{array}$ & 15 & 897 & 84 & 72 & 57 & 113 & 30 & 356 \\
\hline 9 & $\begin{array}{l}\text { Rokan } \\
\text { Hulu }\end{array}$ & 16 & 1.515 & 167 & 90 & 127 & 81 & 115 & 580 \\
\hline 10 & $\begin{array}{l}\text { Rokan } \\
\text { Hilir }\end{array}$ & 15 & 1.869 & 112 & 52 & 107 & 63 & 72 & 406 \\
\hline 11 & Pekanbaru & 12 & 2.448 & 130 & 77 & 70 & 41 & 86 & 404 \\
\hline 12 & Dumai & 7 & 840 & 82 & 44 & 81 & 89 & 61 & 357 \\
\hline & TOTAL & 166 & 17.636 & 1.307 & 907 & 1.194 & 911 & 890 & 5.209 \\
\hline
\end{tabular}

Source: Regional General Election Commission of Riau Province 2019.

Based on the table above it can be seen that the list of voters with disabilities in Riau Province is quite high as seen from the list of voter with disabilities who are physical disability as many as 1,307 persons, blind 907 persons, deaf 1,194 persons, feebleminded 911 persons and other disabilities 890 persons, and the total number is 5,209. Furthermore, it is necessary to make efforts in order to organize political participation of people with disabilities because people with disabilities are part of the success of the election. Moreover, people with disabilities are human beings who have equal human rights since birth, including political rights. In a variety of conditions, people with disabilities have physical and space limitations to participate but that does not mean they are not included in the election. There needs to be a model or other mechanism for them to participate such as the accessibility which adjusts to their needs. Inclusive education is then very important given to them so that they can be integrated with other groups.

From the category of people with disabilities, the feebleminded became public concern ahead of the 2019 election. The existence of multiple perceptions related to the report which said that crazy people's vote became special attention to be clarified which was actually none of them voted, except for people with disabilities (feebleminded) who were given medical certificate which means that they can participate in the election. For feebleminded people who are still hospitalized at the hospital cannot participate because they are still in a state of care or supervision from the hospital. Therefore, these issues arise which are a form of effort to delegitimize the right to vote which then have implication on polemic in the society.

3.2 The Issues of People with Disabilities (Feebleminded) who Join in Giving Their Vote 
Before further examining this issue, there should be equality of meaning related to people with disabilities. Feebleminded person is not a crazy person, but feebleminded person is the one who has the right to vote. However, in giving his vote, the feebleminded person has difficulties. Feebleminded person has some problems such as in terms of remembering, but if he accompanied by someone who helps him in the voting, he could give his voting right. Moreover, this becomes a problem for feebleminded voter, which is difficult to be independent in voting, because he needs an assistant by certain party such as family. Therefore, when the principles of election which are known as "Luber Jurdil" in Bahasa Indonesia, namely (Direct, General, Free, Confidential, Honest and Fair) then for the voter who is feebleminded are not in accordance with the principles of election. For example, it is difficult for the voter to vote without coercion from any party and the vote given by the voter is confidential which is only known by the voter itself. As a result, it is difficult to be justified because feebleminded voter is always accompanied by certain party.

However, the various issues spread in the media related to the voters from crazy people are not true, because the Regional General Election Commission has conducted socialization and clarification through media which can be accessed by the public in order not to cause other views towards the people with disabilities (Feebleminded), because the illness of feebleminded people has existed since their birth, they are mental disability or are called as an idiot but feebleminded people determined by Regional General Election Commission as the organizer of the election that they have the right to participate in giving the right to vote. For this reason, a certain mechanism is needed for the voters who have generally have physical and mental differences. But in fact, there is no distinction between the voters and certain types of people, including people with disabilities so that the voting rights of citizens are still subordinated in a substantial manner which cause them being reluctant to vote.

\subsection{The Movement of Data of People with Disabilities who are Feebleminded}

Political participation is a condition that concerns to the rights of citizens in the political field, including people with disabilities. However, the participation of people with disabilities who are feebleminded in 2019 election in Riau Province is still low. In fact, the existence of people with disabilities cannot be ignored, on the contrary the participation of people with disabilities in accessing political participation is still often considered unimportant. The following is the movement of data of voters with disabilities in Riau Province from the announcement of voter to the determination of final voter list as a result of the second improvement (DPTHP2) as follows:

\begin{tabular}{|l|l|l|l|l|l|}
\hline \multicolumn{7}{|c|}{ Riau Province } \\
\hline $\begin{array}{l}\text { Feebleminded } \\
\text { Voters }\end{array}$ & DP4 & DPS & DPT & DPTHP1 & DPTHP2 \\
\cline { 2 - 6 } & 660 & 888 & 888 & 911 & 911 \\
\hline
\end{tabular}

Source: Regional General Election Commission of Riau Province 2019.

The table above also illustrates the increase in the movement of data of voters with disabilities who are feebleminded, which can be seen from the determination of DP4, DPS, DPT, DPTHP1 and DPTHP2. The movement of feebleminded voters is in line with the movement of the increase of voters in Riau Province. The commitment of the Regional General Election Commission in the effort to encourage voters with disabilities especially those who are feebleminded to participate in 2019 election along with the issue of the involvement of crazy people to vote in various media information. It turns out that the crazy people do not have voting 
rights, whereas what it means is the voters who have mental retardation or better known as feebleminded. The issue of participation also needs to be viewed from a broader aspect, including how the segmentation of voters from various circles. Especially for people with disabilities where in voting process they need help from certain parties to be able or involved in giving voting rights. The participation of feebleminded people in 2019 election still has not reached a significant rate or comparable to the general participation rate. The following table relates to the comparison of political participation of people with disabilities who are feebleminded and general people of Riau Province.

\begin{tabular}{|c|c|c|c|c|}
\hline Voter & $\begin{array}{c}\text { Total } \\
\text { Voter }\end{array}$ & $\begin{array}{c}\text { Political } \\
\text { Participation }\end{array}$ & Not Participate & $\begin{array}{c}\text { The } \\
\text { percentage of } \\
\text { voters (\%) }\end{array}$ \\
\hline Feebleminded & 911 & 410 & 501 & 45 \\
\hline Riau People & 3.863 .305 & 3.103 .378 & 759.987 & 78 \\
\hline
\end{tabular}

Source: Processed data from KPUD Riau Province.

The data from the table above shows that the participation of people with disabilities who are feebleminded is still below the average of Political Participation in Riau Province, which is $78 \%$, compared to the rights that can vote for political participation of people with disabilities is around $45 \%$. If the political participation is an indicator of the success of a democracy, where the conscious involvement of community is a value of the improvement of the quality of democracy but not yet for people with disabilities in Riau Province. The improvement of the quality of democracy is certainly not assed only by procedural but also substantially assessed. Therefore, the increase in the number of voters ahead of the 2019 election in Riau Province is not in line or linear with the participation of people with disabilities who are feebleminded in voting. This becomes particular concern if the feebleminded group will either strengthen or weaken the democratic participation.

Therefore, if the participation of disability group is a part of the successful implementation of democracy just because they are also part of the nation's entity. Then, the implementation of democracy can certainly be traced by examining in depth the application of principles of democracy for people with disabilities in participating on the election through the mechanisms that may not be equated with other general people so that political participation becomes the substance as expected for sake of the realization of democratization in the life of the nation.

\section{Conclusion}

Based on the results of the study above, it can be concluded that political participation for people with disabilities who are feebleminded is still low which is about $45 \%$ and far below the political percentage of Riau people which is $78 \%$, the participation of people with disabilities in using their voting rights is not optimal, because there is no specific mechanism for them to participate in voting such as the access to vote in the Election which has been taking place so far is still generally accepted. Based on the conclusions above, it is necessary to do the improvement of political participation related to the political rights of people with disabilities in the election because their participation is still low. The country must ensure that they can participate effectively and fully on the basis of equality with others people, either directly or through representatives who are freely chosen, including the right and opportunity to vote and 
be elected in accordance with Article 29 of the Convention on the Rights of Persons with Disabilities concerning participation in political and public life.

\section{References}

[1] W. Kumorotomo, Governance Reform di Indonesia: Mencari arah kelembagaan politik yang demokratis dan birokrasi yang profesional. Penerbit Gava Media, 2009.

[2] A. Suharyanto, "Partisipasi Politik Masyarakat Tionghoa dalam Pemilihan Kepala Daerah," JPPUMA J. Ilmu Pemerintah. dan Sos. Polit. Univ. Medan Area, vol. 2, no. 2, pp. 151-160, 2014.

[3] M. Budiardjo, Dasar-dasar Ilmu Politik. Jakarta: PT Gramedia Pustaka Utama, 2010.

[4] E. Y. Lestari and N. Arumsari, "PARTISIPASI POLITIK PEMILIH PEMULA PADA PEMILIHAN WALIKOTA SEMARANG DI KOTA SEMARANG,” Integralistik, vol. 29, no. 1, p. 10,2018

[5] S. Marzuki, Politik hukum hak asasi manusia. Penerbit Erlangga, 2014.

[6] P. R. K. Dewi, "Aksesbilitas Partisipasi Politik Penyandang Disabilitas Dalam Pemilu Di Kota Denpasar," 2015.

[7] R. Gustomy, "Partisipasi Politik Difabel Di 2 Kota,” Indones. J. Disabil. Stud., vol. 4, no. 1, pp. 51-62, 2017.

[8] A. Yandra, "Fisibilitas Pilkada Serentak Tahap II Kota Pekanbaru Pasca Permendagri No 18 Tahun 2015," J. Niara, vol. 9, no. 2, pp. 62-74, 2017. 